\title{
Significance of novel bioinorganic anodic aluminum oxide nanoscaffolds for promoting cellular response
}

This article was published in the following Dove Press journal:

Nanotechnology, Science and Applications

I4 January 201 I

Number of times this article has been viewed

\section{Gérrard Eddy Jai Poinern \\ Robert Shackleton \\ Shariful Islam Mamun \\ Derek Fawcett}

Murdoch Applied Nanotechnology Research Group, Department of Physics, Energy Studies and Nanotechnology, School of Engineering and Energy, Murdoch University, Murdoch, Western Australia, Australia
Correspondence: Gérrard Eddy Jai Poinern Murdoch Applied Nanotechnology Research Group, Department of Physics, Energy Studies and Nanotechnology, School of Engineering and Energy,

Murdoch University, Murdoch, Western Australia 6I50, Australia

Tel +6I 893602892

Fax +61893606183

Email g.poinern@murdoch.edu.au

\begin{abstract}
Tissue engineering is a multidisciplinary field that can directly benefit from the many advancements in nanotechnology and nanoscience. This article reviews a novel biocompatible anodic aluminum oxide (AAO, alumina) membrane in terms of tissue engineering. Cells respond and interact with their natural environment, the extracellular matrix, and the landscape of the substrate. The interaction with the topographical features of the landscape occurs both in the micrometer and nanoscales. If all these parameters are favorable to the cell, the cell will respond in terms of adhesion, proliferation, and migration. The role of the substrate/scaffold is crucial in soliciting a favorable response from the cell. The size and type of surface feature can directly influence the response and behavior of the cell. In the case of using an AAO membrane, the surface features and porosity of the membrane can be dictated at the nanoscale during the manufacturing stage. This is achieved by using general laboratory equipment to perform a relatively straightforward electrochemical process. During this technique, changing the operational parameters of the process directly controls the nanoscale features produced. For example, the pore size, pore density, and, hence, density can be effectively controlled during the synthesis of the AAO membrane. In addition, being able to control the pore size and porosity of a biomaterial such as AAO significantly broadens its application in tissue engineering.
\end{abstract}

Keywords: anodic aluminum oxide, nanoscaffolds, cellular response, tissue engineering

\section{Introduction}

The last two decades have seen a remarkable eruption of fundamental research into nanotechnology and nanoscience. Current research in material science, engineering, biotechnology, and biomedical fields has clearly demonstrated the many possible applications of nanotechnology. ${ }^{1,2}$ The foundation of this research exploration is based on the fact that nanoscale matter can have significantly different properties than its bulk counterparts. ${ }^{3,4}$ The discovery and investigation of these unknown properties, using new advanced characterization techniques, should provide detailed information that can be used to develop many new nanoderived applications. These new characterization techniques have come about from the development of the atomic force microscope and the scanning tunneling microscope (scanning probe microscopy ${ }^{5}$ ) in the 1980 s. Both these devices have allowed researchers to delve and map the properties of these newly created nanomaterials. In addition, as the knowledge base in nanotechnology and nanoscience increases, it will create opportunities to develop these new nanomaterials to their full potential. These new developments will create many varied applications and will also generate new superior tools to assist in current therapies as well as provide the foundations for new avenues of biomedical intervention in the near future. 
To date, there are numerous processing techniques capable of manufacturing nanomaterials, but recent studies have focused on refining these processes to produce new nanoscale materials. Processes such as chemical vapor deposition to produce carbon nanotubes and carbon nanostructures, ${ }^{6,7}$ ultrasonic methods to produce nanohydroxyapatite crystals for biomedical applications, ${ }^{8,9}$ and the wet sol-gel synthesis method of creating iron oxide $\left(\mathrm{Fe}_{2} \mathrm{O}_{3}\right)$ nanoparticles ${ }^{10,11}$ are a few techniques that are currently being investigated and refined to produce high-quality nanomaterials. The most attractive feature of nanotechnology is in developing new manufacturing techniques that can give researchers far greater control over the polydiversity, phase, crystalline structure, typography, and quality of the nanomaterials produced.

While cells are generally in the micrometer-size range, their component structures and associated environment are generally in the nanometer to submicrometer range. Indeed, the molecular building blocks of life: proteins, carbohydrates, nucleic acids, and lipids, are all nanosized structures. Importantly, the interaction between the cell and nanostructures such as proteins are crucial for controlling cell functions such as proliferation, migration, and the production of the extracellular matrix (ECM) ${ }^{12}$ (Figure 1). Furthermore, the physical structure and chemistry of the nanostructure directly influence the behavior of the cell in contact with the surface. For example, how the surface influences the adhesive attachment of the cell to the surface and its subsequent influence on the proliferation of anchorage-dependent cells is still to be determined. It should also be mentioned that the adsorption of proteins by the surface nanostructures is highly dependent on the nature of the surface; for example, surface charge, surface chemistry, ${ }^{13}$ wettability, ${ }^{14}$ surface density of cell-binding ligands, ${ }^{15}$ and nanotopography ${ }^{16}$ play an important role in cell-substrate interaction. For example, current research in the use of bioimplant materials by Yao et al have shown that nanometer topography enhances the adhesion of osteoblast

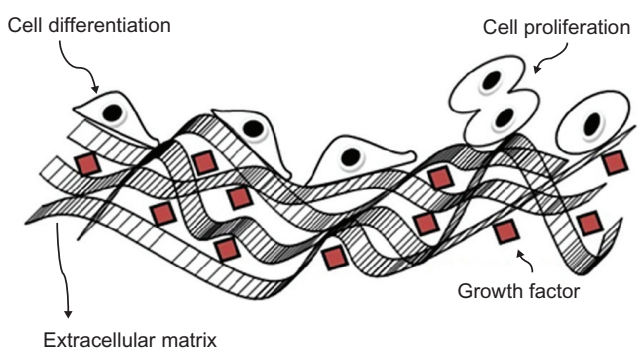

Figure I Schematic representation of the cellular environment with the cells and its extracellular matrix. cells onto $\mathrm{Ti}_{6} \mathrm{Al}_{4} \mathrm{~V}$ and anodized $\mathrm{Ti}$ surfaces. ${ }^{17,18}$ However, studies by Webster et al have revealed an enhanced function of osteoblast cells attaching to nanoceramic materials. ${ }^{19}$ This review focuses on the significance of using a novel biocompatible anodic aluminum oxide (AAO) membrane as a nanoscaffold for promoting cellular growth for tissue engineering applications.

\section{Tissue engineering}

The field of tissue engineering came into existence during the mid-1980s. Its creation resulted from the convergence of several scientific and technological fields to address the high demands for regenerated tissues. The primary function of tissue engineering is to recreate the appropriate signals to cells that promote biological processes, which can then create new and/or repair damaged tissues by rational design. According to Langer and Vacanti, ${ }^{20}$ tissue engineering is a highly interdisciplinary field that applies the principles of engineering and life sciences toward the development of biological alternatives that restore, maintain, or improve tissue function.

A major function of tissue engineering is to create an environment that can promote productive and efficient cellular activity; however, this environment is influenced by a number of tissue-dependent factors. The work of Yang et al has shown that tissue engineering is composed of four key factors: 1) cells, 2) scaffolds, 3) bioreactors, and 4) signals. ${ }^{21}$ It should be noted that an exhaustive examination of these key factors is required to achieve the most appropriate contribution from each step for the particular tissue being addressed. In effect, determining, developing, and instituting the most appropriate environment which will provide the optimum conditions for tissue regeneration. The first step involves the harvesting of appropriate cells from donor sites and the subsequent seeding of these cells onto an appropriate scaffold that is contained within a suitable growing medium. The scaffold structure promotes cell and tissue development by providing a three-dimensional (3D) environment, where the cells can attach and proliferate. ${ }^{22}$ Apart from being 3D, the scaffold should be highly porous to allow for the diffusion of nutrients, oxygen, and waste products and also be made from biocompatible degradable nontoxic material. ${ }^{23}$ This is where nanotechnology can have a significant role to play. This is because nanotechnology permits the individualized creation of a scaffold structure that can be specifically designed for the particular tissue type and can be enhanced to provide the maximized environmental conditions for optimal cellular growth. 
Many studies have shown that cells in general tend to behave more naturally when they are cultivated in a 3D-scaffold environment. ${ }^{24}$ This has resulted in the design of 3D scaffolds that incorporate tissue-specific topographical and environmental enhancements. For example, cells that were cultivated on scaffolds containing $10-100-\mu \mathrm{m}$-sized ridges and grooves promoted elongated cell growth that was orientated in the direction of the surface feature. ${ }^{25}$ These topological features provide contact guidance for the cell, which influences the cytoskeletal arrangement and adhesion of the cell. ${ }^{26}$ Similar studies of cultivated cells on scaffolds containing arrays of micrometer-sized protrusions have promoted cell attachment and reduced cell proliferation. ${ }^{27}$ These studies have clearly shown that controlling the surface features of the scaffold in a specific way can directly influence cellular adhesion, protein absorption, proliferation, and morphology. In addition, cells can also change their microenvironments on the scaffold structure by modifying the ECM it produces. This can be done by synthesizing or degrading the ECM, secreting cytokines, and communicating with other cells and matrix on the scaffold by molecular and physical signals. ${ }^{28}$ It is clear that the interaction between the individual cells, the ECM, and the nanostructures of the scaffold is a dynamic process and is crucial to fully understand the cellular response as a whole in developing suitable biomaterials for tissue engineering.

\section{Scaffold materials}

The application of biomaterials in tissue engineering for tissue repair and regeneration has generally favored bioinert materials for permanent bioimplants such as hip replacements. In addition, in the case of scaffolding materials, both natural and inorganic, including metal oxides, have been investigated. Natural biodegradable materials have been extensively studied for possible use in tissue engineering since the body's natural pathways can easily handle the breakdown of their by-products. Natural polymers such as polysaccharides, ${ }^{29-33}$ chitosan, ${ }^{34-39}$ and hyaluronic-based derivatives $\mathrm{s}^{40-43}$ and protein-based materials such as fibrin gel ${ }^{44,45}$ and collagen ${ }^{46-49}$ have shown some positive outcomes, but on the whole, these polymeric materials lack sufficient mechanical strength. On the other hand, inorganic or synthetic biodegradable polymers have been fabricated under controlled conditions to produce scaffolds with tunable, predictable mechanical and physical properties.

Biopolymers are based on simple, high-purity constituent monomers. These biopolymers have lower toxicity reactions with the body, and their degradation rate can be easily controlled. Examples of bulk biodegradable polymers include poly(lactic acid) (PLA), ${ }^{50-55}$ poly(L-lactic acid) (PLLA), ${ }^{48,56-58}$ poly(lactic-co-glycolic acid) (PLGA), ${ }^{59-62}$ polycaprolactone (PCL),,$^{57,63-65}$ and poly(glycolic acid) (PGA). ${ }^{66-69}$ These are generally poly- $\alpha$-hydroxy esters that de-esterify in the body as the polymer degrades to simple metabolites. ${ }^{70}$ Currently available biodegradable sutures in clinical use are made from PLA and PGA. In addition, since polymers are an effective biocompatible material, they have also been extensively investigated for the controlled delivery of drugs to specific organs within the body. ${ }^{71-73}$ Polymers are generally strong and can be made into different shapes and structures, such as pellets, disks, films, and fibers, as required for the specific application. In addition, they can be produced with microtypographical surface features that can enhance cell interaction with the surface of the scaffold.

Inorganic materials such as bioglass, ceramics, and metal oxides have also been investigated for possible use in tissue engineering applications. This research stream stems from the fact that even though polymers have been successfully used in tissue engineering, there are still some unresolved issues to be addressed. The first results from the local inflammation response to the polymer material, and the second results from the uneven degradation of this bioscaffold. However, for softtissue applications such as skeletal muscle, cardiovascular tissue, and skin substitutes, polymer scaffolds are superior to ceramics and metal oxides. This advantage stems from the fact that polymers have close similarity to both the chemical and the mechanical properties of the natural tissues. ${ }^{74-76}$ Studies using bioactive glass as a scaffold material have shown that when the glass material was seeded with osteoblasts, there was a positive effect on cellular proliferation. ${ }^{77}$ In addition, metals such as pure tantalum $(\mathrm{Ta})$ have also been found to provide a suitable substrate for the adhesion, growth, and differentiation of osteoblasts. One novel method of creating a metallic scaffold using Ta begins with the pyrolysis of polyurethane foam. ${ }^{78}$ The foam turns into a low-density carbonaceous skeleton composed of a repeating dodecahedron structure that produces an interconnecting array of pores. In the next stage, a chemical vapor deposition/infiltration technique (CVD/CVI) is used to deposit pure Ta onto the carbon skeleton and produce a porous metal scaffold. The structural integrity of the scaffold increases as the deposition process continues. This deposition also results in a crystallographic growth pattern that orientates the Ta layer to form a microtextured surface that is similar to cancellous bone. ${ }^{79,80}$ In this technique, changing the characteristics of the precursor polymer used and the thickness of the Ta layer 
deposited onto the carbon skeleton can vary the pore size. For orthopedic applications, the thickness of the Ta layer ranges from 40 to $60 \mu \mathrm{m}$, the pore size ranges from 400 to $600 \mu \mathrm{m}$, and the resulting porosity of the material varies from $75 \%$ to $80 \%$. The high porosity and large pore size are ideal for deep and extensive vascular tissue penetration. The vascular tissue penetration and subsequent growth result in strong tissue attachment strengths. ${ }^{81}$ In addition, image analysis of a similar, highly porous alumina ceramic foam metal has confirmed the vascular tissue penetration and subsequent growth in a similar scaffold structure to that of Ta. ${ }^{82}$ Furthermore, investigations involving the growth of osteoblasts on the surface of metal oxides, such as nanoporous alumina, have also shown positive results. ${ }^{83,84}$ The remainder of this review article will focus only on nanoscale structures for tissue engineering.

\section{Requirements for a successful scaffold structure}

The operational demands that are placed on the scaffold structure are numerous, and the scaffold must overcome many challenges to achieve a successful clinical outcome. For example, biocompatibility is crucial so as not to elicit any cytotoxicity, immunological reactions, and inflammation responses from the body. ${ }^{85-87}$ The scaffold structure provides the initial framework onto which the cells can attach, proliferate, and differentiate. In this process, the initial scaffold mimics the ECM environment, and as the new ECM is being created, it will provide integrity to the new tissues as the scaffold slowly degrades. The surface chemistry of the scaffold material is a critical parameter; this is because the scaffold must be chemically compatible with the ECM. Since the ECM forms the cell environment, it is desirable that the scaffold mimics the ECM as close as possible, and in so doing, it will promote cell adhesion, cellular interaction, proliferation, and migration. ${ }^{47}$

In addition, the scaffolding material must be able to cope with the mechanical stresses resulting from the growth stages as well as prevent any rapid bulk degradation effects that might produce voids within the structure. The material must also be easily sterilized prior to application without any significant changes to its surface chemistry. ${ }^{47,88-91}$ At the molecular level, it is extremely important that the scaffold contains a network of pores and interconnecting channels to facilitate the diffusion of nutrients, oxygen, metabolites, and waste products. The materials used in the construction of the scaffold should not be hydrophobic, so the wettability of the material must be carefully considered for successful cell adhesion and attachment. Kim and Coulombe showed that pore size and a high surface area to volume ratio are also important parameters in encouraging the growth and penetration of cells into the structure to form cellular associations. ${ }^{92}$ In addition, if the scaffold structure is going to be large, then the structure should be designed to contain a life-supporting capillary-like network as part of the scaffold. In addition, it should be mentioned that the nanotopography of the scaffold structure has also been shown by many to influence cell attachment and adhesion, proliferation, and migration. A recent investigation by Andersson et al revealed the link between epithelial cell attachments to surfaces of similar chemistry. Furthermore, the morphology and cell cytokine production were strongly dependent on the underlying nanotopography. ${ }^{93}$

\section{Submicro/nanoscaffold fabrication techniques}

The structure of the ECM is fibrous in nature and has features at both the nanoscale and/or the submicrometer level. Developing engineering materials that mimic the ECM is the goal of many research teams worldwide. In nanotechnology, the manufacture of regular nanosized structures by means of lithographic techniques has generally required the use of expensive ultrahigh vacuum equipment. This top to bottom technology has spurred on the miniaturization of electronic devices and personal computers for the past three decades. There have also been numerous other techniques developed over the years, and many of these have been applied to tissue engineering; electron beam lithography has been used to produce nanoscale patterns on the surface of several biocompatible materials, but the technique is relatively expensive and time consuming. Photolithography, X-ray lithography, laser ablation, and nanoimprinting lithography have also been used. Lithography techniques emboss various patterned nanostructures into the surface of the material; this changes the topographic features of the surface to solicit a positive cellular response. Unfortunately, there have been relatively few cell culture studies done on many of these techniques. Two recent developments in nanotechnology, of note, to produce polymeric nanoscaffolds are the refinement of electrospinning and phase separation techniques. ${ }^{94-97}$

Originally developed by the textile industry, electrospinning has been used for the past 100 years. Refinements in the technique in the last decade have seen it increasingly used in the manufacture of nanofibrous polymer scaffolds. Membranes of PLA and PLGA, fibroin, and collagen have been produced using this technique. Agarwal et $\mathrm{al}^{49}$ 
has demonstrated that materials manufactured using this technique induce a favorable and conducive response from the cells during attachment and subsequent proliferation. This nanofibrous electrospun material can be further bioengineered to resemble the ECM at the nanoscale level by coating the material with collagen macromolecules. This technique is still evolving, and there are still challenges ahead.

Other nanopolymeric substrates have been manufactured using phase separation techniques that have produced a thin membrane of the desired polymer. Recent developments to this technique have produced membranes with nanofeatures embedded in the surface to enhance the cell response of this material. ${ }^{89,98,99}$ Investigations by Ma have revealed that nanopolymers produced using this technique have a distinct advantage in terms of the increased surface area and the resulting enhanced 3D connectivity for various cell types in tissue engineering applications..$^{71,100}$

\section{Nanoporous AAO}

Aluminum (Al) is a soft, durable, lightweight, and malleable metal and is the most abundant metal in the Earth's crust. It is rather reactive and forms an impervious layer of oxide, $\mathrm{Al}_{2} \mathrm{O}_{3}$. Because of the metal's high strength to weight ratio, its use steadily increased during the last century. The interest in alumina ceramic as a biomaterial has its origins in the 1970 s when Hamadouche et $\mathrm{al}^{101}$ successfully used it as a clinical hip implant replacement. In recent years, with the advent of nanotechnology, the well-established electrochemical procedure of $\mathrm{Al}$ anodization has been revisited and used to manufacture nanoporous $\mathrm{Al}_{2} \mathrm{O}_{3}$ membranes for tissue engineering applications. The controlled formation of regular pores in the AAO layer ranges from micrometersized holes to the much smaller nanosized holes, both of which can be generated without expensive equipment and instrumentation. This process is electrochemically driven, and a schematic representation of the experimental setup is presented in Figure 2. Through the manipulation of parameters such as the nature and strength of the acid, the voltage applied, and the exposure time of the Al to the electrolyte, tunable nanopores can be generated. The advantage of this process is that the size of the regular pores can be easily controlled at the macroscopic level.

The detailed study of porous alumina started more than five decades ago with Keller et al ${ }^{102}$ in 1953. They reported on the detailed structure of the pore, the effect of the solvent action of different electrolytes on the oxide coating, and the voltage dependence on the pore size (see Figure 3 ). In the early stages of the anodization process,

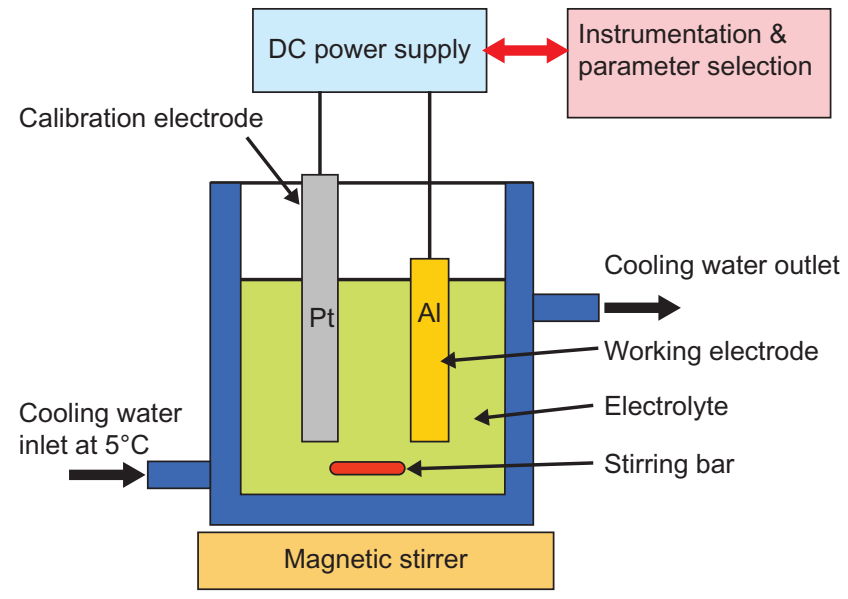

Figure 2 A schematic representation of a typical experimental setup for the anodization of aluminum.

$\mathrm{Al}^{3+}$ ions migrate from the metal across the metal/oxide interface into the forming oxide layer. ${ }^{110}$ Meanwhile, $\mathrm{O}^{2-}$ ions formed from the electrolyte at the oxide/electrolyte interface travel into the oxide layer. During this stage, $\sim 70 \%$ of the $\mathrm{Al}^{3+}$ ions and the $\mathrm{O}^{2-}$ ions contribute to the formation of the barrier layer, the remaining $\mathrm{Al}^{3+}$ ions are dissolved into the electrolyte. ${ }^{111}$ This condition has been shown to be the prerequisite for porous oxide growth, in which the $\mathrm{Al}-\mathrm{O}$ bonds in the oxide lattice break to release $\mathrm{Al}^{3+}$ ions. ${ }^{112}$ During the oxide formation, the barrier layer constantly regenerates with further oxide growth and transforms into a semispherical oxide layer of constant thickness that forms the pore bottom, as shown in Figure 4. The steady-state growth results from the balance between the field-enhanced oxide dissolution at the oxide/electrolyte interface at the base of the hemispherical-shaped pores where the electric field is high enough to propel the $\mathrm{Al}^{3+}$ ions through the barrier layer and the oxide growth at the metal/oxide

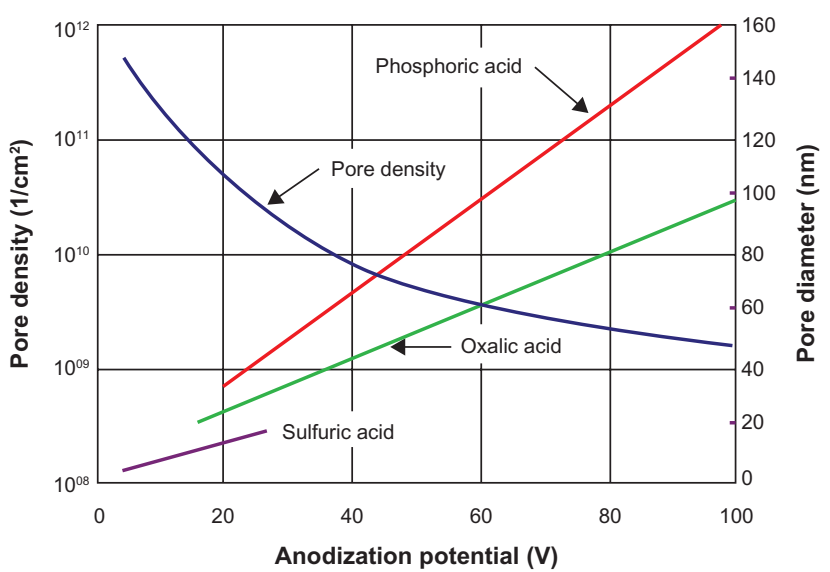

Figure 3 The effect of electrolyte and anodization potential on pore diameter and pore density. ${ }^{103-109}$ 


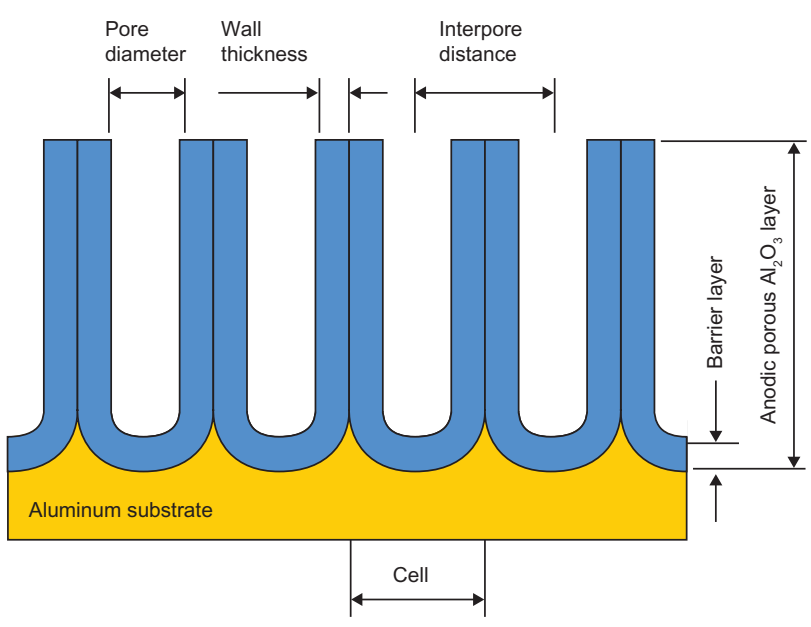

Figure 4 The porous aluminum oxide layer formed during anodization.

interface resulting from the migration of $\mathrm{O}^{2-}$ and $\mathrm{OH}^{-}$ions into the pore base oxide layer. ${ }^{113,114}$ This also explains the dependence of the size of the pore diameter to the electric field produced by the anodizing voltage. It should also be noted that the electric field strength in the pore walls is too small to make any significant contribution to the flow of ions. ${ }^{115}$ The oxidation takes place over the entire pore base, and the resulting oxide material grows perpendicular to the surface, the neighboring pore growth preventing growth in any other direction. The vertical growth of the pore wall creates a columnar structure with a high aspect ratio that contains a central circular channel. This channel extends from the base of the pore to the surface of the oxide layer. This formation mechanism explains the dependence of pore size (Figure 3), porosity and oxide growth rate (Figure 5), and interpore distance and pore wall thickness (Figure 6) on the applied voltage and electrolyte composition.

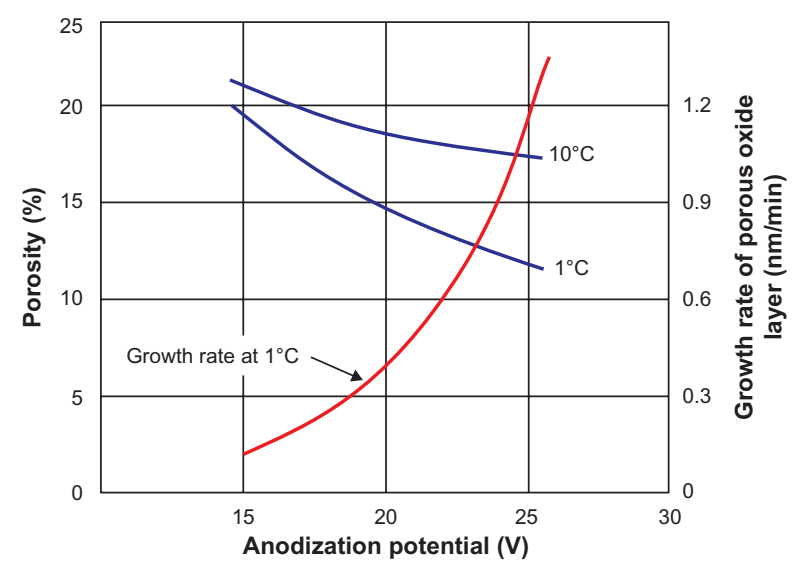

Figure 5 The effect of temperature and anodization potential on the growth rate and porosity of an aluminum oxide being formed in a $2.4 \mathrm{M}$ sulfuric acid electrolyte. ${ }^{106,108,109,116}$

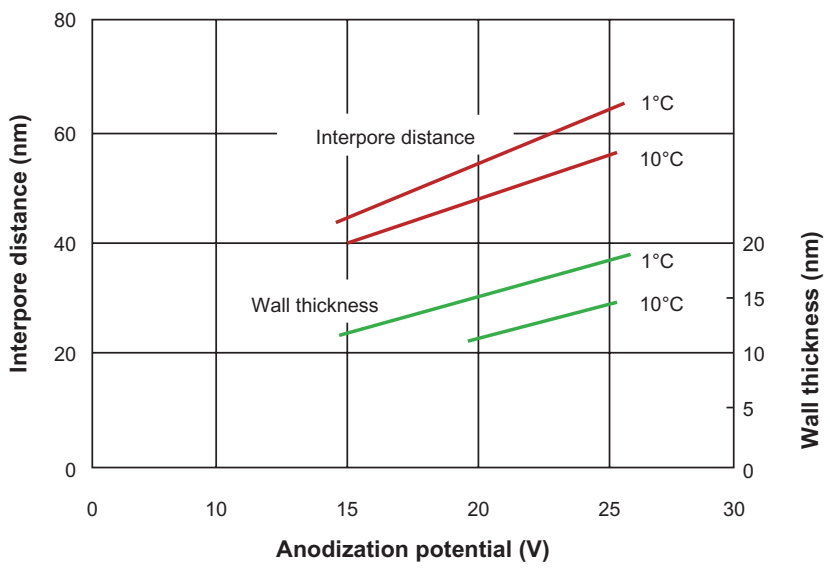

Figure 6 The effect of temperature and anodization potential on the interpore distance and the wall thickness of the pore during formation in $2.4 \mathrm{M}$ sulfuric acid electrolyte. ${ }^{106,108,109,116}$

Unfortunately, the progress in AAO development slowed in the following decade. It was not until 1995, when Masuda and Fukuda reported the formation of a highly regular and dense honeycomb AAO structure formed by a two-step anodization process that a renewed interest in using AAO membranes as a template to develop nanostructured materials was vigorously pursued. ${ }^{117}$ Masuda and Satoh explained that the oxide growth of the aluminum substrate caused the formation of a nanodimpled landscape, which in turn provided an essential template for the second anodization step. ${ }^{118}$ Jessensky et al found that the organized arrangement of neighboring pore in hexagonal arrays are due to the repulsive interactions between the pores and the loss of $\mathrm{Al}^{3+}$ ions, which is also the prerequisite for porous oxide growth. ${ }^{119}$ The strong interest in understanding the formation mechanisms in producing nanoporous AAO continued in the new millennium with Wang and Han optimizing the two-step anodization process. The optimized process was able to obtain highly ordered structures, and the increased exposure time to the phosphoric acid affected the pore diameter ${ }^{104}$ (Figure 7). They suggested that this was the result of the etching effect of the acid, which caused the thinning of both the outer and inner surfaces of the AAO.

\section{Cell response to $\mathrm{AAO}$}

There are four fundamental tissue types in the human body: the epithelium, which is responsible for absorbing or secreting materials and for protecting tissue surfaces; muscular tissue, which is responsible for the movements of body organs such as the digestive tract and for skeletal movement; the connective tissue, the most widely distributed tissue in the body supports and connects other tissues together; and 


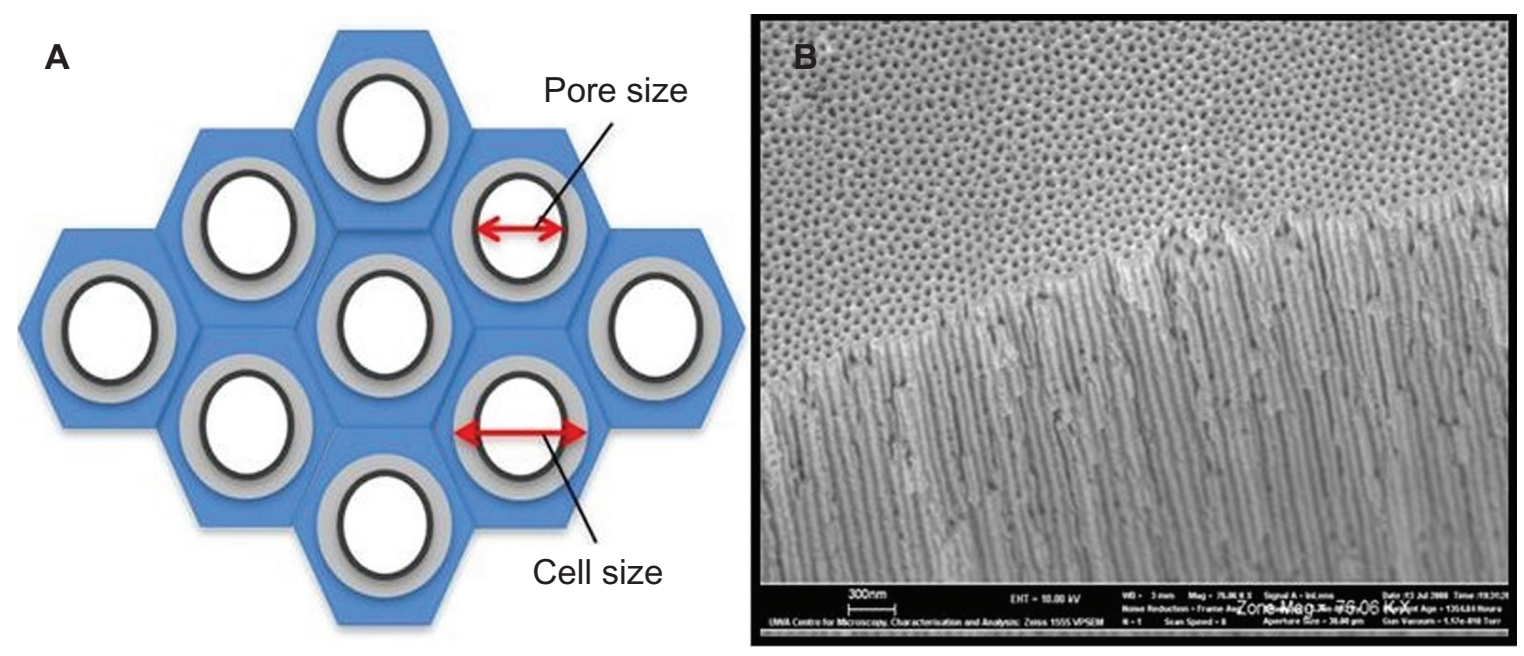

Figure 7 Porous anodic aluminum oxide structures. A) Idealized schematic representation of the hexagonal cells. B) Actual membrane with nanopores and channels.

finally, nervous tissue, which is capable of receiving stimuli and transferring signal and then bringing about a response.

The tissues are composed of individual cells and the ECM, and each cell in the tissue structure has adapted to undertake specific functions and grouped together with other cells to work efficiently for the survival of the tissue/ organ as a whole. Within the tissues, there are numerous specialized cell types; these cell types differ from each other in nature, the function they perform, and the arrangement of the individual cells and the ECM components. For example, fibroblastic, epithelial, and endothelial cells are anchorage dependent, which means that they must adhere to a proper ECM structure in order to survive. Recent studies of fibroblasts, epithelial cells, and smooth muscle cells have shown that cell adhesion diminishes as the scaffold softens and that the cells would migrate to regions where the scaffold is more rigid. ${ }^{120}$ In addition, the interactions between cells and topographical features at the microsize such as pores, posts, embossed patterns, ridges, and grooves have been extensively studied. ${ }^{121,122}$ This article focuses on the interaction of several cell types with the nanotopography of an AAO substrate. The topography of the substrate in all cases directly affects the basic cell functions. The interaction between cell and nanotopography in conjunction with the physicochemical properties of the substrate or scaffold can induce different effects within a single cell type. These effects vary across the cell types, the size of the feature, and its geometry. The following sections examine the cellular interaction of specific cell types with an AAO substrate being used as a scaffold for tissue engineering applications. Some cell lines have been investigated to varying degrees, while others are yet to be studied.

\section{Osteoblasts for bone tissue replacement}

Bone tissue is a $3 \mathrm{D}$ organic-inorganic ceramic composite matrix composed of collagen fibrils with embedded wellarrayed nanocrystalline rod-shaped and plate-shaped inorganic calcium phosphate apatite materials of $25-50 \mathrm{~nm}$ in length. ${ }^{123,124}$ This composite structural material is capable of withstanding compression and tensile loading that the skeletal system experiences on a daily basis. Bone tissue engineering procedures have been developed to replace and/or regenerate damaged bone tissue. These procedures have used a wide variety of materials, which have been developed in the past to address particular biofunctionality and biocompatibility issues associated with the application. There are basically four groups of materials used; these are metals, ceramics, polymers, and composites. The orthopedic field generally uses metals such as cobalt-chrome steel alloys, stainless steel, titanium, and titanium alloys as bioimplants. ${ }^{125}$ Ceramics such as aluminum oxide, carbon, calcium phosphates apatites, and glass ceramics have been used in applications ranging from hip replacements to bone cements. Numerous polymers such as poly(ethylene) (usually of high molecular weight), poly(lactides), poly(methyl methacrylates), and poly(urethane) have been used in applications ranging from dental implants to components in joint replacements. Unfortunately, since no one material has been able to meet all the biofunctionality and biocompatibility issues associated with bone replacement and tissue engineering applications, composite materials have been developed and used. For example, calcium phosphate apatites such as hydroxyapatite are being used to coat metal implants in order to make them more biocompatible with the surrounding body tissues. 
At the cellular level, recent investigations into developing scaffolds with nanotopography for bone and cartilage repair or replacement has examined a variety of materials and surface features. Scaffolds composed of carbon nanofibers/ polymer composites were investigated by Price et al, and their study revealed that nanotopography of the carbon nanofibers provided a favorable environment for bone-producing cells and promoted osteoblastic adhesion. ${ }^{126}$ Similar studies with nanofibrous scaffolds created from nanopolymer/ nanohydroxyapatite composites, which resembled the ECM, revealed that protein absorption was substantially increased, which in turn increased adhesion. ${ }^{127}$

In terms of AAO membranes and ceramic substrates, the interaction of osteoblasts with the ceramic medium has been very positive. Investigations by Webster et al have revealed that the interaction between osteoblasts and nanoceramic materials was substantially enhanced in their 2000 study. ${ }^{19}$ In a similar study by Karlsson et al this positive effect could be seen in the interaction between nanoporous alumina sheets and osteoblasts. ${ }^{128}$ Their study also suggested that by varying the pore size, it could also be possible to control the response of species such as proteins from the cell to the coating ${ }^{129}$ and hence be able to influence cellular attachment, differentiation, and mineralization taking place. This is an important factor when you consider that vascular tissue does not appear to penetrate into pores with diameters smaller than $100 \mu \mathrm{m} .{ }^{130}$ The pore size used in the Karlsson et al study was around $200 \mathrm{~nm}$ in diameter, about the same size as the cellular filipodia, thus indicating the nanopore structures were being used as anchorage points for the cells.

In addition, Karlsson et al also investigated the reported negative effect of $\mathrm{Al}^{3+}$ ions on bone mineralization. The results of their study indicated that there was a very small leakage of $\mathrm{Al}^{3+}$ ions from the nanoporous alumina to the surrounding media. After 9 days, the $\mathrm{Al}^{3+}$ ion leakage had only accounted for $0.03 \%$ of the original alumina membrane weight. ${ }^{128}$ The following comparative studies undertaken by Karlsson et al indicated that this small leakage was far from toxic. In fact, the leakage rate was considered to be within the range that is normally considered to be beneficial for the stimulation of osteoblasts. ${ }^{131}$ This response has also been investigated by other researchers who have found that $\mathrm{Al}^{3+}$ ions tend to stimulate the proliferation and differentiation of osteoblasts. ${ }^{132,133}$

Furthermore, La Flamme et al have clearly demonstrated the biocompatibility of the nanoporous AAO membrane for use as a scaffold, ${ }^{134}$ and Popat et al have demonstrated that marrow stromal cells can differentiate on nanoporous AAO membranes ${ }^{84}$ The porous nature of this membrane makes it an almost 'prefect' candidate for a scaffold material since osteoblasts cells are accustomed to surviving in a largely porous environment. This is where the macroscopic manipulation of the pore size of the membrane is critical and can readily be adjusted for specific tissue engineering purposes.

\section{Fibroblasts and keratinocytes \\ for skin tissue replacement}

The skin forms part of the integumentary system of the human body and has the important role of protecting the internal environment of the body. This protection is essential to ward off bacterial, viral, fungal, yeasts, and other pathogenic agents that are present in the surrounding environment. In addition, the skin shields the internal organs from shock and physical trauma. The human skin is the largest organ in the body; it can be between $10 \%$ and $20 \%$ of the total body weight, and its surface area ${ }^{135}$ can cover $\sim 1-2 \mathrm{~m}^{2}$.

The skin is a highly specialized and multilayered organ with several important functions. It assists in the generation of vitamin D with the assistance of UV rays from the sun, and this generates the compound calcitriol, which contributes to bone health. The skin also reduces the loss of fluids from the body and participates in the homeostatic regulation of the body's temperature with respect to the environment. Other homeostatic functions performed are the excretion of excess water, salts, urea, and lactic acid by the action of sweat glands, which are embedded in the skin.

The three main layers that make up the skin structure consist of the epidermis, which is the outermost layer in contact with the environment. Next is the dermis, which forms the middle layer and is in direct contact with the basal layer (or hypodermis), which is the third and innermost of the layers (Figure 8). The epidermis is composed of the stratified

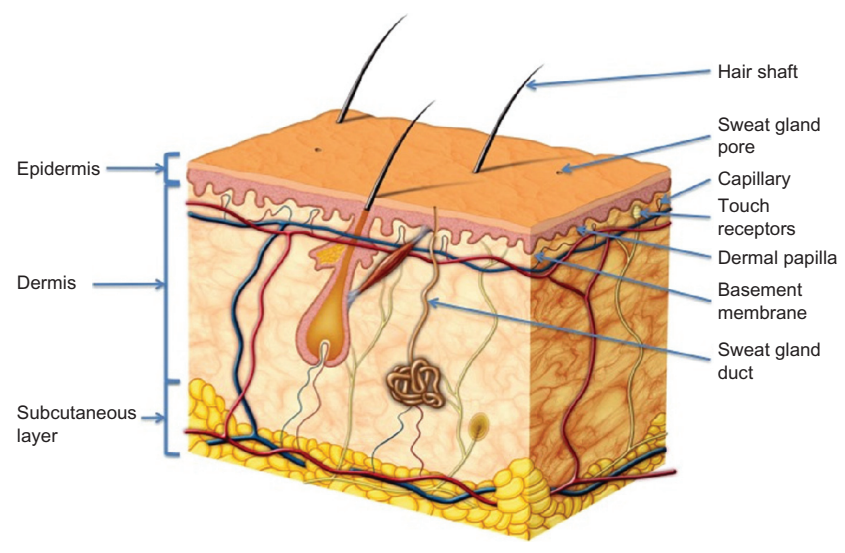

Figure 8 Schematic representation of the cross section of the skin. Copyright (C) 201 I, Fotolia LLC. Reproduced with permission from Skin Anatomy by Andrea Danti. 
squamous epithelium, which is replaced every 35-45 days. It is made up of five distinct layers; stratum basale, stratum spinosum, stratum granulosum, stratum lucidum, and stratum corneum. The last layer, which is the outermost and exposed to the environment, is largely made up of dead skin cells filled with keratin pigment. The epidermal cells consist of keratinocytes, stem cells, melanocytes, dendritic cells, and Merkel cells. The dermis is made up of two layers; namely, the papillary and the reticular layer, both of which form a strong flexible gel-like matrix of connective tissue composed of elastic reticular fibers and collagen that gives the skin its strength and resilience. The dermis also contains many nerves and blood and lymph vessels. In addition, the hair follicles and sweat glands are also contained within this layer. The final layer is the hypodermis or subcutaneous, which is largely composed of adipose tissue and connective tissue and anchors the skin to underlying tissues. It has two main functions; the first is to absorb mechanical shock, and secondly, it act as a thermal insulator. ${ }^{46,136,137}$

There have been extensive studies carried out on fibroblast response to a variety of scaffold materials and nanotopographics. ${ }^{138-141}$ These studies have revealed that in the majority of cases, adhesion increases as the height and area dimensions of the nanofeature decreases. This trend is also seen as the morphology and the configuration of the cytoskeleton change. In addition, changing the nanotopographic features of the substrate also solicited different cell responses. However, to date, there has been very little research carried out that has studied the response of fibroblasts and keratinocytes to AAO membranes.

Due to the high clinical demand for skin repair products, tissue engineering techniques have been used to produce suitable tissue replacements. The nanoporous AAO membrane has been investigated for possible use as a scaffold for growing replacement skin tissue from cells originally sourced from the patient. A recent study by Parkinson et al has shown that keratinocytes and fibroblast epidermal cells adhered to these nanoporous membranes. ${ }^{142}$ The study also found that the pore size influenced the rate of cell proliferation and migration. An example of such a nanoporous AAO membrane being manufactured for a cell trial is shown in Figure 7.

The AAO membrane, with its nanotopographical features selected, is initially seeded with skin cells (keratinocytes and fibroblast epidermal cells). These cells are then encouraged to proliferate and allowed to form a confluent layer (Figure 9). This cellular layer can then be lifted from the AAO and applied to the wound bed directly, or it can be added with the AAO membrane facing out. A direct advantage of the latter

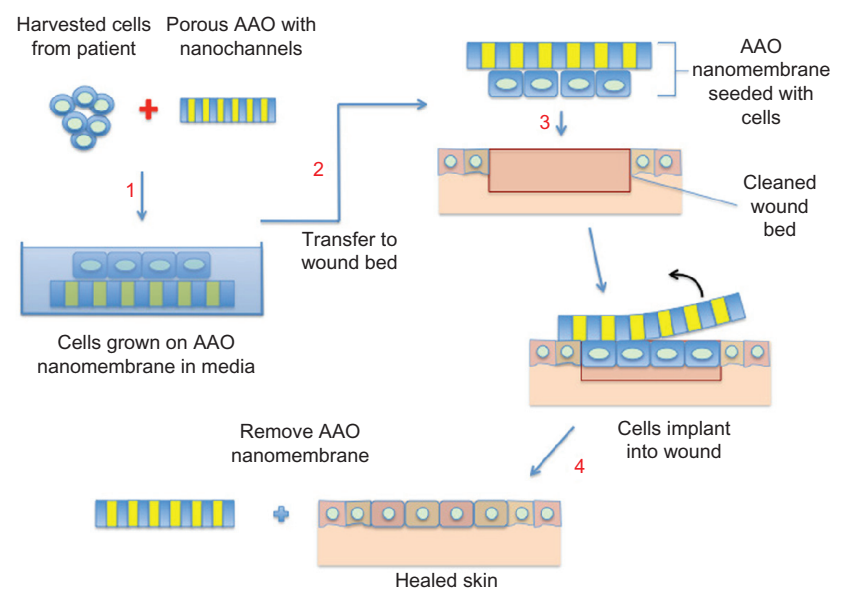

Figure 9 Schematic representation of the anodic aluminum oxide (AAO) membrane used as a 'band-aid technique' for skin tissue engineering.

'band-aid' technique is that it would allow the exchange of gases/fluids through the nanochannels (breathable) and can, at the same time, stop micrometer-sized bacterial infection. Once the autologous cells have been incorporated into the wound bed, the outer AAO membrane can then be safely removed.

Another advantage of this type of technology for skin tissue engineering application is the total absence of animalderived feeder layers, which can be expensive and have a strict regulatory protocol attached to their implementation. In addition, being totally inorganic, this membrane can be sterilized more efficiently than its polymeric counterpart. In burns trials, this manufactured AAO membrane is about 50-200 $\mu \mathrm{m}$ thick and is not as rigid as the normal alumina ceramic that is used for hard-tissue applications such as bone implant. Because of this level of flexibility, this alumina membrane can, therefore, be contoured to conform to various skin/body shapes. ${ }^{142}$

Moreover, the research has also shown that keratinocytes and fibroblast epidermal cells are sensitive to changes in the nanotopography of the AAO membrane. The authors are currently investigating further the interactions between the cells and the nanoengineered AAO surface.

\section{Hepatocytes}

There has been very little tissue engineering research into the interaction between hepatocytes and nanotopographical features on a substrate surface. Chua et al have shown that there was some effect on rat hepatocytes on electrospun polymer fibers that formed the scaffold body. ${ }^{143}$ On the other hand, in 2007 Hoess et al were able to use AAO membranes as a substrate for the hepatoma cell line HepG2 and demonstrate that this cell line adheres and proliferates on the membrane homogeneously. They also found that larger pore diameters 
$(230 \mathrm{~nm})$ appeared to give a greater opportunity for newly seeded HepG2 cells to anchor to the membrane and assisted the culture medium to reach all cells on the membrane. Furthermore, it was shown that nanoporous AAO membrane could be used as cell culture substrate for further tissue engineering application such as the bioartificial liver. ${ }^{144}$

\section{Leukocytes}

The response of leukocytes and endothelial cells to nanotopography on polymers has been investigated by Buttiglieri et al. ${ }^{145}$ The study revealed that the response of leukocytes was dependent upon the height of the nanoislands with the cell adhesion increasing while the height of the island decreased. It was also found that leukocytes adhesion was also dependent upon the amount of endothelial cell attachment. This study also indicated that the changes in the nanotopography (island height increasing) increased endothelization, which resulted in decreased leukocyte adhesion. In addition, leukocytes were found not to respond favorably to nanoengineered gratings. Moreover, in the case of an AAO membrane, Karlsson et al found that membranes with pore sizes ranging from 20 to $200 \mathrm{~nm}$ could be used beneficially to promote leukocytes growth and morphology. ${ }^{83}$ Since there has been very little work done on this cell line on AAO membranes, it would be interesting to investigate further the nanotopography of the oxide membrane and its possible use as a biomaterial in vascular blood-related applications.

\section{Epithelial, smooth muscle, endothelial, stem, and nerve cells}

A recent investigation of epithelial cells by Andersson et al has revealed a link between the cells attachment to the surface of a substrate with similar chemistry. In addition, the morphology and cytokine production were strongly dependent on the underlying nanotopography. ${ }^{93}$ However, to date, there is no definitive relationship established between the geometry of the surface features, the dimensions of the features, and the cell interaction.

One epithelial cell line that is currently being investigated by the authors is the Madin-Darby Canine Kidney. These cell cultures on AAO substrates are an ideal way to study the adhesion, proliferation, and migration of cells that have the potential to be used as a model to study some cellular functions of the kidney (Figure 10).

The interaction of both smooth muscle cells and endothelial cells with microtopography and nanotopography features on polymer substrate surfaces has been extensively studied. Tissue engineering applications of these cell types include vascular grafts and bladder replacement implants. ${ }^{146-148}$ To date, no research has been done using AAO membranes as a scaffold for these types of tissues.

One of the greatest achievements in the past decade has been the discovery and the fast tracking of stem cell technology for numerous applications. Stem cells are immature or differentiated cells that are capable of regeneration and differentiation into a variety of more specialized cell types in response to appropriate signals. These cells have recently been recognized as a more suitable alternative to mature cells. This is because stem cells can be easily harvested from donor sites and cultured into a wide range of tissues. These advantages make the stem cell an attractive tool for the repair of damaged or defective tissues and organs in the body. Currently, they are being used in a variety of tissue engineering applications such as bone, cartilage,

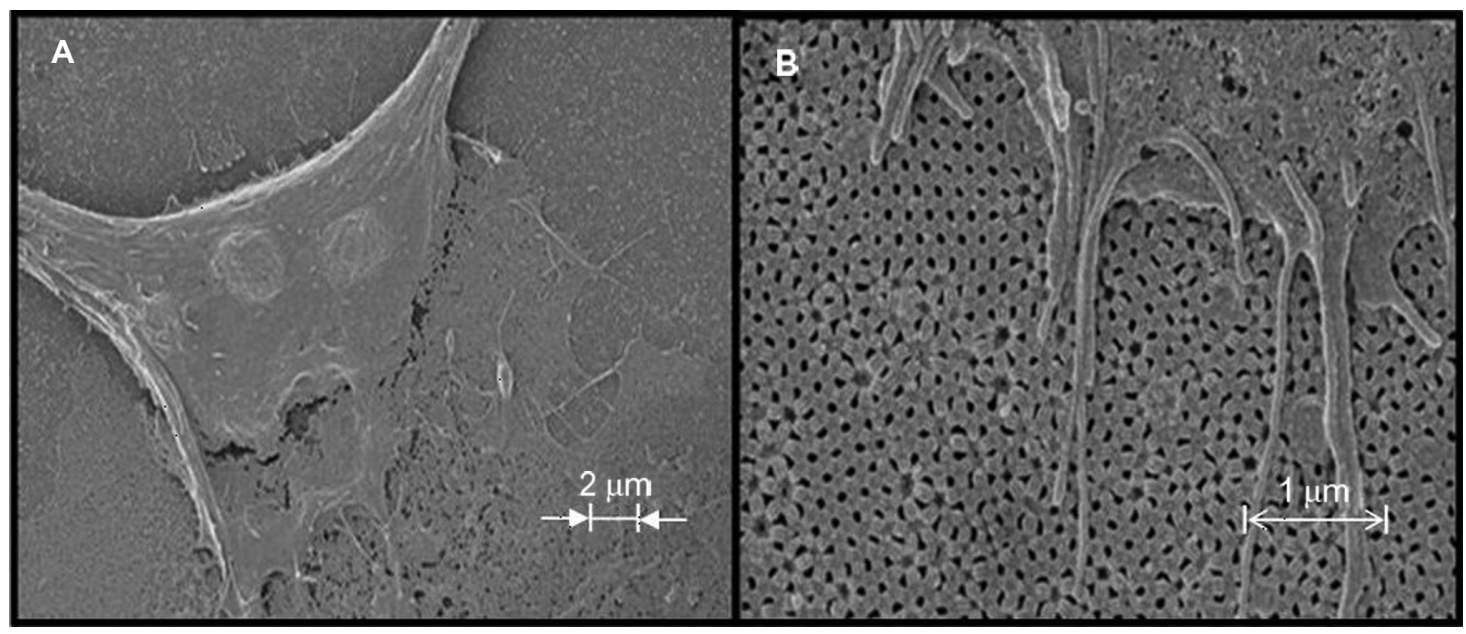

Figure 10 Evidence of adhesion and attachment of Madin-Darby Canine Kidney (MDCK) epithelial cells onto the anodic aluminum oxide membrane made using oxalic acid ( $0.3 \mathrm{M}$ oxalic acid at $60 \mathrm{~V}$ for $5 \mathrm{~h}$ (first anodization step) and $3 \mathrm{~h}$ (second anodization step) at $4^{\circ} \mathrm{C}$. A) MDCK epithelial cell with $2-\mu \mathrm{m}$ scale bar. B) MDCK epithelial cell with I- $\mu \mathrm{m}$ scale bar. 
liver, nerve, and dermal tissues. ${ }^{149-151}$ The current research at this stage does not include the use of AAO substrate materials, so there are no data to indicate the possible cellular responses to this material, given the array of data obtained on AAO. It would be advantageous to investigate any interaction between stem cells and various pore sizes of the AAO membranes.

There have been investigations into templates and scaffolds for neuron tissue engineering using materials such as chitosan, but to date, there has been no work carried out using AAO as a scaffold or substrate. ${ }^{152}$

\section{Conclusion}

The continuing research into unraveling the complex interaction between the cell and its environment, the ECM, and the surface features of synthetic scaffold structures holds the keys to solving many of the current problems associated with tissue engineering and its wider application into the biomedical field. Recent developments in nanotechnology have enabled the creation of new materials and techniques that can be used to mimic the environment of the cell. This review presents the results of preliminary investigations that were carried out to verify the viability of using AAO, a new biocompatible inorganic scaffold material, for tissue engineering applications. The manufacture of the AAO scaffold material allows the direct control of the nanoscale features produced. Being able to control the pore size and porosity of the AAO scaffold structure enables the surface of material to be tailored to a specific tissue engineering application. Initial results have indicated that cell response to this material is positive and that the cells adhere to the surface, proliferate, and migrate. The surface topography of this nanoarchitectured material and pore structure of the AAO scaffold appear to actively encourage cellular interaction. Further research is needed to fully examine and exploit this novel biocompatible material for the developing field of tissue engineering. This article clearly indicates that the interdisciplinary field of tissue engineering in combination with the relatively new field of nanotechnology holds the keys to many new and innovative developments in the future.

\section{Acknowledgments}

This work was supported by the Western Australian Nanochemistry Research Institute (WANRI). Dr Derek Fawcett thank WANRI for the research fellowship. We thank Ms Xuan Thi Le and Ms Nurshahidah Ali for the schematic and FESEM images in this article.

\section{Disclosure}

The authors report no conflicts of interest in this work.

\section{References}

1. Nouailhat A. An Introduction to Nanoscience and Nanotechnology. New York, NY: John Wiley; 2008.

2. Poole CP Jr, Owens FJ. Introduction to Nanotechnology. Hoboken, NJ: John Wiley; 2003.

3. Ozin GA, Arsenault AC, Cademartiri L. Nanochemistry: A Chemical Approach to Nanomaterials. London, UK: Royal Society of Chemistry; 2005:473-517.

4. Cao G. Nanostructures and Nanomaterials: Synthesis, Properties and Applications. London, UK: Imperial College Press; 2004.

5. Reimer L. Scanning Electron Microscopy: Physics of Image Formation and Microanalysis. 2nd ed. Heidelberg, Germany: Springer; 1998.

6. Singh C, Shaffer MSP, Windle AH. Production of controlled architectures of aligned carbon nanotubes by an injection chemical vapour deposition method. Carbon. 2003;41(2):359-368.

7. Bower C, Zhou O, Zhu W, Werder D. Nucleation and growth of carbon nanotubes by microwave plasma chemical vapor deposition. Appl Phys Lett. 2000;77(17):2767-2769.

8. Titanic K, Iwafune K, Howell FS, Aizawa M. Preparation of various calcium-phosphate powders by ultrasonic spray freeze-drying technique. Mater Res Bull. 2000;35(4):575-585.

9. Poinern GE, Brundavanam RK, Mondinos N, Jiang ZT. Synthesis and characterisation of nanohydroxyapatite using an ultrasound assisted method. Ultrason Sonochem. 2009;16(4):469-474.

10. Camponeschi E, Walker J, Garmestani H, Tannenbaum R. Surfactant effects on the particle size of iron (III) oxides formed by sol-gel synthesis. J Non Cryst Solids. 2008;354(34):4063-4069.

11. Khalil KMS, Makhlouf SA. High surface area thermally stabilized porous iron oxide/silica nanocomposites via a formamide modified sol-gel process. Appl Surf Sci. 2008;254(13):3767-3773.

12. Yim EK, Leong KW. Significance of synthetic nanostructures in dictating cellular response. Nanomedicine. 2005;1(1):10-21.

13. Rappaport C. Small aspect of the growth of mammalian cells on glass surfaces. In: Hair ML, editor. The Chemistry of Bio Surfaces. New York, NY: Marcel Dekker; 1972:449-489.

14. Volger EA. Interfacial chemistry in biomaterials science. In: Berg JC, editor. Wettability. New York, NY: Marcel Dekker; 1993:184-250.

15. Grinnell F. Cellular adhesives and extracellular substrata. Int Rev Cytol. 1978;53:65-144.

16. Christenson EM, Anseth KS, van den Beucken JJ, et al. Nanobiomaterial applications in orthopedics. J Orthop Res. 2007;25(1):11-22.

17. Webster TJ, Smith TA. Increased osteoblast function on PLGA composites containing nanophase titania. J Biomed Mater Res A. 2005; 74(4):677-686.

18. Yao C, Perla V, McKenzie JL, Slamovich EB, Webster TJ. Anodized Ti and $\mathrm{Ti}_{6} \mathrm{Al}_{4} \mathrm{~V}$ possessing nanometer surface features enhances osteoblast adhesion. J Biomed Nanotechnol. 2005;1(1):68-73.

19. Webster TJ, Ergun C, Doremus RH, Siegel RW, Bizios R. Enhanced functions of osteoblasts on nanophase ceramics. Biomaterials. 2000; 21(17): 1803-1810.

20. Langer R, Vacanti JP. Tissue engineering. Science. 1993;260:920-926.

21. Yang F, Neeley WL, Moore MJ, Karp JM, Shukla A, Langer R. Tissue engineering: the therapeutic strategy of the twenty-first century. In: Laurencin CT, Nair LS, editors. Nanotechnology and Tissue Engineering: The Scaffold. Boca Raton, FL: Taylor \& Francis Group, LLC; 2008:3-24.

22. Lutolf MP, Hubbell JA. Synthetic biomaterials as instructive extracellular micro environments for morphogenesis in tissue engineering. Nat Biotechnol. 2005;23(1):47-55.

23. Liu C, Xia Z, Czernuszka JT. Design and development of threedimensional scaffolds for tissue engineering. Chem Eng Res Des. 2007;85(7):1051-1064. 
24. Langer R, Tirrell DA. Designing materials for biology and medicine. Nature. 2004;428(6982):487-492.

25. Thakar RG, Cheng Q, Patel S, et al. Cell-shape regulation of smooth muscle cell proliferation. Biophys J. 2009;96(8):3423-3432.

26. Oh S, Brammer KS, Julie-Li YS, et al. Stem cell fate dictated solely by altered nanotube dimension. Proc Natl Acad Sci U S A. 2009;106(7): 2130-2135.

27. Norman JJ, Collins JM, Sharma S, Russell B, Desai TA. Microstructures in 3D biological gels affect cell proliferation. Tissue Eng Part A. 2008;14(3):379-390.

28. Hynes RO. Integrins: bidirectional, allosteric signaling machines. Cell. 2002;110(6):673-687.

29. Yang L, Zhang LM. Chemical structural and chain conformational characterization of some bioactive polysaccharides isolated from natural sources. Carbohydr Polym. 2009;76(3):349-361.

30. Sinha VR, Kumria R. Polysaccharides in colon-specific drug delivery. Int J Pharm. 2001;224(1-2):19-38.

31. Crini G. Recent developments in polysaccharide-based materials used as adsorbents in wastewater treatment. Prog Polym Sci. 2005;30(1): $38-70$.

32. Kanazawa A, Suzuki M. Solid-state poly-condensation of natural aldopentoses and 6-deoxyaldohexoses. Facile preparation of highly branched polysaccharide. Polymer. 2006;47(1):176-183.

33. Sun RC, Fang JM, Goodwin A, Lawther JM, Bolton AJ. Fractionation and characterization of polysaccharides from abaca fibre. Carbohydr Polym. 1998;37(4):351-359.

34. Ravi Kumar MNV. A review of chitin and chitosan applications. React Funct Polym. 2000;46(1):1-27.

35. Wang X, Du Y, Luo J, Lin B, Kennedy JF. Chitosan/organic rectorite nanocomposite films: structure, characteristic and drug delivery behaviour. Carbohydr Polym. 2007;69(1):41-49.

36. Dang JM, Leong KW. Natural polymers for gene delivery and tissue engineering. Adv Drug Deliv Rev. 2006;58(4):487-499.

37. Lorenzo-Lamosa ML, Remuñan-López C, Vila-Jato JL, Alonso MJ. Design of microencapsulated chitosan microspheres for colonic drug delivery. J Control Release. 1998;52(1-2):109-118.

38. George M, Abraham TE. Polyionic hydrocolloids for the intestinal delivery of protein drugs: alginate and chitosan - a review. $J$ Control Release. 2006;114(1):1-14.

39. Thacharodi D, Rao KP. Development and in vitro evaluation of chitosanbased transdermal drug delivery systems for the controlled delivery of propranolol hydrochloride. Biomoterials. 1995;16(2):145-148.

40. Halbleib M, Skurk T, de Luca C, von Heimburg D, Hauner H. Tissue engineering of white adipose tissue using hyaluronic acid-based scaffolds: in vitro differentiation of human adipocyte precursor cells on scaffolds. Biomaterials. 2003;24(18):3125-3132.

41. Jagur-Grodzinski J. Biomedical application of functional polymers. React Funct Polym. 1999;39:99-138.

42. Cascone MG, Sim B, Downes S. Blends of synthetic and natural polymers as drug delivery systems for growth hormone. Biomaterials. 1995;16(7):569-574.

43. Kafedjiiski K, Jetti RKR, Föger F, et al. Synthesis and in vitro evaluation of thiolated hyaluronic acid for mucoadhesive drug delivery. Int J Pharm. 2007;343(1-2):48-58.

44. Jockenhoevel S, Zund G, Hoerstrup SP, et al. Fibrin gel - advantages of a new scaffold in cardiovascular tissue engineering. Eur J Cardiothorac Surg. 2001;19(4):424-430.

45. Ryan EA, Mockros LF, Stern AM, Lorand L. Influence of a natural and a synthetic inhibitor of factor XIIIa on fibrin clot rheology. Biophys $J$. 1999;77(5):2827-2836.

46. Chun TH, Hotary KB, Sabeh F, Saltiel AR, Allen ED, Weiss SJ. A pericellular collagenase directs the 3-dimensional development of white adipose tissue. Cell. 2006;125(3):577-591.

47. Dai NT, Williamson MR, Khammo N, Adams EF, Coombes AG. Composite cell support membranes based on collagen and polycaprolactone for tissue engineering of skin. Biomaterials. 2004;25(18): 4263-4271.
48. Sato T, Chen G, Ushida T, et al. Evaluation of PLLA-collagen hybrid sponge as a scaffold for cartilage tissue engineering. Mater Sci Eng C. 2004;24(3):365-372.

49. Agarwal S, Wendorff JH, Greiner A. Progress in the field of electrospinning for tissue engineering applications. Adv Mater. 2009; 21(32-33):3343-3351.

50. Dong Y, Feng SS. Methoxy poly(ethylene glycol)-poly(lactide) (MPEG-PLA) nanoparticles for controlled delivery of anticancer drugs. Biomaterials. 2004;25(14):2843-2849.

51. Zheng X, Kan B, Gou M, et al. Preparation of MPEG-PLA nanoparticle for honokiol delivery in vitro. Int J Pharm. 2010;386(1-2):262-267.

52. Chen J, Tian B, Yin X, et al. Preparation, characterization and transfection efficiency of cationic PEGylated PLA nanoparticles as gene delivery systems. J Biotechnol. 2007;130(2):107-113.

53. Kranz H, Bodmeier R. Structure formation and characterization of injectable drug loaded biodegradable devices: in situ implants versus in situ microparticles. Eur J Pharm Sci. 2008;34(2-3):164-172.

54. Kanczler JM, Ginty PJ, Barry JJ, et al. The effect of mesenchymal populations and vascular endothelial growth factor delivered from biodegradable polymer scaffolds on bone formation. Biomaterials. 2008;29(12):1892-1900.

55. Rimondini L, Nicoli-Aldini N, Fini M, Guzzardella G, Tschon M, Giardino R. In vivo experimental study on bone regeneration in critical bone defects using an injectable biodegradable PLA/PGA copolymer. Oral Surg Oral Med Oral Pathol Oral Radiol Endod. 2005;99(2):148-154.

56. Chu CFL, Lu A, Liszkowski M, Sipehia R. Enhanced growth of animal and human endothelial cells on biodegradable polymers. Biochim Biophys Acta. 1999;1472(3):479-485.

57. Calandrelli L, Immirzi B, Malinconico M, Volpe MG, Oliva A, Della Ragione F. Preparation and characterisation of composites based on biodegradable polymers for "in vivo" application. Polymer. 2000;41(22): 8027-8033.

58. Wang Z, Wang S, Marois Y, Guidoin R, Zhang Z. Evaluation of biodegradable synthetic scaffold coated on arterial prostheses implanted in rat subcutaneous tissue. Biomaterials. 2005;26(35):7387-7401.

59. Aubert-Pouëssel A, Venier-Julienne MC, Clavreul A, et al. In vitro study of GDNF release from biodegradable PLGA microspheres. $J$ Control Release. 2004;95(3):463-475.

60. Qiao M, Chen D, Ma X, Liu Y. Injectable biodegradable temperatureresponsive PLGA-PEG-PLGA copolymers: synthesis and effect of copolymer composition on the drug release from the copolymer-based hydrogels. Int J Pharm. 2005;294(1-2):103-112.

61. Lee JJ, Lee SG, Park JC, Yang YI, Kim JK. Investigation on biodegradable PLGA scaffold with various pore size structure for skin tissue engineering. Curr Appl Phys. 2007;7(Suppl 1):e37-e40.

62. Yoo HS, Park TG. Biodegradable polymeric micelles composed of doxorubicin conjugated PLGA-PEG block copolymer. $J$ Control Release. 2001;70(1-2):63-70.

63. Todo M, Park SD, Takayama T, Arakawa K. Fracture micromechanisms of bio-absorbable PLLA/PCL polymer blends. Eng Frac Mech 2007;74(12):1872-1883.

64. Rezgui F, Swistek M, Hiver JM, G'Sell C, Sadoun T. Deformation and damage upon stretching of degradable polymers (PLA and PCL). Polymer. 2005;46(18):7370-7385.

65. Li B, Yu J, Jung J, Ree M. Amidolysis of some biodegradable polymers. Polym Degrad Stab. 1999;65(1):161-163.

66. Iwasaki Y, Sawada S, Ishihara K, Khang G, Lee HB. Reduction of surface-induced inflammatory reaction on PLGA/MPC polymer blend. Biomaterials. 2002;23(18):3897-3903.

67. Li Y, Nothnagel J, Kissel T. Biodegradable brush-like graft polymers from poly(D,L-lactide) or poly(D,L-lactideco-glycolide) and chargemodified, hydrophilic dextrans as backbone - synthesis, characterization and in vitro degradation properties. Polymer. 1997;38(25):6197-6206.

68. Wang YC, Lin MC, Wang DM, Hsieh HJ. Fabrication of a novel porous PGA-chitosan hybrid matrix for tissue engineering. Biomaterials. 2003;24(6):1047-1057. 
69. Hsieh CY, Tsai SP, Wang DM, Chang YN, Hsieh HJ. Preparation of $\gamma$-PGA/chitosan composite tissue engineering matrices. Biomaterials. 2005;26(28):5617-5623.

70. Rezwan K, Chen QZ, Blaker JJ, Boccaccini AR. Biodegradable and bioactive porous polymer/inorganic composite scaffolds for bone tissue engineering. Biomaterials. 2006;27(18):3413-3431.

71. Kreuter J. Nanoparticulate systems for brain delivery of drugs. $A d v$ Drug Deliv Rev. 2001;47(1):65-81.

72. Han ML, Lowman AM. Biodegradable nanoparticles for drug delivery and targeting. Curr Opin Solid State Mater. 2002;6(4):319-327.

73. Blaker JJ, Knowles JC, Day RM. Novel fabrication techniques to produce microspheres by thermally induced phase separation for tissue engineering and drug delivery. Acta Biomater. 2008;4(2):264-272.

74. Ramakrishna S. Ramalingam M, Sampath Kumar TS, Soboyejo WO. Recent trends in biomaterials. In: Biomaterials: A Nano Approach. 1st ed. Boca Raton, FL: CRC Press; 2010:22-27.

75. Greco RS, Prinz FB, Smith RL, editors. Nanoscale Technology in Biological Systems. 1st ed. Boca Raton, FL: CRC Press; 2005.

76. Lines MG. Nanomaterials for practical functional uses. JAlloys Compd. 2008;449(1-2):242-245.

77. Misra SK, Mohn D, Brunner TJ, et al. Comparison of nanoscale and microscale bioactive glass on the properties of $\mathrm{P}(3 \mathrm{HB}) /$ bioglass composites. Biomaterials. 2008;29(12):1750-1761.

78. Koutsostathis SD, Tsakotos GA, Papakostas I, Macheras GA Biological processes at bone - porous tantalum interface. J Orthop. 2009;6(4):e3.

79. Bobyn JD, Wilson GJ, MacGregor DC, Pilliar RM, Weatherly GC. Effect of pore size on the peel strength of attachment of fibrous tissue to porous-surfaced implants. J Biomed Mater Res. 1982;16(5):571-584.

80. Bobyn JD, Toh KK, Hacking SA, Tanzer M, Krygier JJ. Tissue response to porous tantalum acetabular cups: a canine model. J Arthroplasty. 1999;14(3):347-354.

81. Hacking SA, Bobyn JD, Toh KK, Tanzer M, Krygier JJ. Fibrous tissue in growth and attachment to porous tantalum. J Biomed Mater Res A. 2000;52(4):631-638.

82. Khalil A, Aponte C, Zhang R, et al. Image analysis of soft-tissue in-growth and attachment into highly porous alumina ceramic foam metals. Med Eng Phys. 2009;31(7):775-783.

83. Karlsson M, Johansson A, Tang L, Boman M. Nanoporous aluminum oxide affects neutrophil behaviour. Microsc Res Techn. 2004;63(5):259-265.

84. Popat KC, Chatvanichkul KI, Barnes GL, Latempa TJ Jr, Grimes CA, Desai TA. Osteogenic differentiation of marrow stromal cells cultured on nanoporous alumina surfaces. J Biomed Mater Res A. 2007;80(4): 955-964.

85. Veronese FM, Schiavon O, Pasut G, et al. PEG-doxorubicin conjugates: influence of polymer structure on drug release, in vitro cytotoxicity, bio-distribution, and antitumor activity. Bioconjug Chem. 2005;16(4): 775-784

86. Wong HL, Rauth AM, Bendayan R, et al. A new polymer-lipid hybrid nanoparticle system increases cytotoxicity of doxorubicin against multidrug-resistant human breast cancer cells. Pharm Res. 2006;23(7): $1574-1585$.

87. Timmer MD, Shin H, Horch RA, Ambrose CG, Mikos AG. In vitro cytotoxicity of injectable and biodegradable poly(propylene fumarate)based networks: unreacted macromers, cross-linked networks, and degradation products. Biomacromolecules. 2003;4(4):1026-1033.

88. Peters EC, Petro M, Svec F, Fréchet JM. Molded rigid polymer monoliths as separation media for capillary electrochromatography. 1. Fine control of porous properties and surface chemistry. Anal Chem. 1998; 70(11):2288-2295.

89. Kunzler TP, Drobek T, Schuler M, Spencer N. Systematic study of osteoblast and fibroblast response to roughness by means of surfacemorphology gradients. Biomaterials. 2007;28(13):2175-2182.

90. Miller DC, Thapa A, Haberstroh KM, Webster TJ. Endothelial and vascular smooth muscle cell function on poly(lactic-co-glycolic acid) with nano-structured surface features. Biomaterials. 2004;25(1):53-61.
91. Ibn-Elhaj M, Schadt M. Optical polymer thin films with isotropic and anisotropic nano-corrugated surface topologies. Nature. 2001; 410(6830):796-799.

92. Kim S, Coulombe PA. Intermediate filament scaffolds fulfill mechanical, organizational, and signaling functions in the cytoplasm. Genes Dev. 2007;21(13):1581-1597.

93. Andersson AS, Bäckhed F, von Euler A, Richter-Dahlfors A, Sutherland D, Kasemo B. Nanoscale features influence epithelial cell morphology and cytokine production. Biomaterials. 2003;24(20): 3427-3436.

94. Li WJ, Laurencin CT, Caterson EJ, Tuan RS, Ko FK. Electrospun nanofibrous structure: a novel scaffold for tissue engineering. J Biomed Mater Res. 2002;60(4):613-621.

95. Schindler M, Ahmed I, Kamal J, et al. A synthetic nanofibrillar matrix promotes in vivo-like organization and morphogenesis for cells in culture. Biomaterials. 2005;26(28):5624-5631.

96. Hu Y, Grainger DW, Winn SR, Hollinger JO. Fabrication of poly(alpha-hydroxy acid) foam scaffolds using multiple solvent systems. J Biomed Mater Res. 2002;59(3):563-572.

97. Chun KW, Cho KC, Kim SH, Jeong JH, Park TG. Controlled release of plasmid DNA from biodegradable scaffolds fabricated using a thermally-induced phase-separation method. J Biomater Sci Polym Ed. 2004;15(11):1341-1353.

98. Liu X, Lim JY, Donahue HJ, Dhurjati R, Mastro AM, Vogler EA. Influence of substratum surface chemistry/energy and topography on the human fetal osteoblastic cell line hFOB 1.19: phenotypic and genotypic responses observed in vitro. Biomaterials. 2007;28(31): 4535-4550.

99. Keselowsky BG, Collard DM, García AJ. Surface chemistry modulates fibronectin conformation and directs integrin binding and specificity to control cell adhesion. J Biomed Mater Res A. 2003;66(2):247-259.

100. Ma PX. Biomimetic materials for tissue engineering. Adv Drug Deliv Rev. 2008;60(2):184-198.

101. Hamadouche M, Boutin P, Daussange J, Bolander ME, Sedel L. Alumina-on-alumina total hip arthroplasty: a minimum 18.5-year follow-up study. J Bone Joint Surg Am. 2002;84-A(1):69-77.

102. Keller F, Hunter MS, Robinson DL. Structural features of oxide coatings on aluminum. J Electrochem Soc. 1953;100(9):411-419.

103. Zhao Y, Chen M, Zhang Y, Xu T, Liu W. A facile approach to formation of through-hole porous anodic aluminum oxide film. Mater Lett. 2005;59(1):40-43.

104. Wang X, Han GR. Fabrication and characterization of anodic aluminium oxide template. Microelectron Eng. 2003;66(1-4):166-170.

105. Zhao NQ, Jiang XX, Shi CS, Li JJ, Zhao ZG, Du XW. Effects of anodizing conditions on anodic alumina structure. J Mater Sci. 2007; 42(11):3878-3882.

106. Suh JS, Lee JS. Highly ordered two-dimensional carbon nanotube arrays. Appl Phys Lett. 1999;75(14):2047-2049.

107. Sadasivan V, Richter CP, Menon L, Williams PF. Electrochemical selfassembly of porous alumina template. AIChE J. 2005;51(2):649-655.

108. Sulka GD, Parkola K. Anodising potential influence on well-ordered nanostructures formed by anodisation of aluminium in sulphuric acid. Thin Solid Films. 2006;515(1):338-345.

109. Sulka GD. Highly ordered anodic porous alumina formation by selforganized anodizing. In: Eftekhai A, editor. Nanostructured Materials in Electrochemistry. Weinheim, Germany: Wiley-VCH; 2008:1-116.

110. Patermarakis G. Development of a theory for the determination of the composition of the anodizing solution inside the pores during the growth of porous anodic $\mathrm{Al}_{2} \mathrm{O}_{3}$ films on aluminium by a transport phenomenon analysis. J Electroanal Chem. 1998;447(1-2):25-41

111. Palbroda E. Aluminium porous growth - II. On the rate determining step. Electrochim Acta. 1995;40(8):1051-1055.

112. Shawaqfeh AT, Baltus RE. Fabrication and characterization of single layer and multi-layer anodic alumina membrane. J Memb Sci. 1999;157(2):147-158.

113. Hoar TP, Mott NF. A mechanism for the formation of porous anodic oxide films on aluminium. J Phys Chem Solids. 1959;9(2):97-99. 
114. O'Sullivan JP, Wood GC. The morphology and mechanism of formation of porous anodic films on aluminium. Proc R Soc Lond A Math Phys Sci. 1970;317:511-543.

115. Thompson GE, Furneaux RC, Wood GC, Richardson JA, Goode JS. Nucleation and growth of porous anodic films on aluminium. Nature. 1978;272(5652):433-435.

116. De Azevedo WM, de Carvalho DD, Khoury HJ, de Vasconcelos EA, da Silva EF Jr. Spectroscopic characteristics of doped nanoporous aluminum oxide. Mater Sci Eng B. 2004;112(2-3):171-174.

117. Masuda H, Fukuda K. Ordered metal nanohole arrays made by a two-step replication of honeycomb structures of anodic alumina. Science. 1995;268(5216):1466-1468.

118. Masuda H, Satoh M. Fabrication of gold nanodot array using anodic porous alumina as an evaporation mask. Jpn J Appl Phys. 1996;35(2): L126-L129.

119. Jessensky O, Müller F, Gösele U. Self-organized formation of hexagonal pore arrays in anodic alumina. Appl Phys Lett. 1998;72(10): $1173-1175$.

120. Discher DE, Mooney DJ, Zandstra PW. Growth factors, matrices, and forces combine and control stem cells. Science. 2009;324(5935): 1673-1677.

121. Wilkinson CDW. Nanostructures in biology. Microelectron Eng. 1995;27(1-4):61-65.

122. Barbucci R, Pasqui D, Wirsen A, Affrossman S, Curtis A, Tetta C. Micro and nano-structured surfaces. J Mater Sci Mater Med. 2003; 14(8):721-725.

123. Weiner S, Wagner HD. The material bone: structure-mechanical function relations. Аппи Rev Mater Sci. 1998;28:271-298.

124. Hellmich C, Ulm FJ. Average hydroxyapatite concentration is uniform in the extracollagenous ultrastructure of mineralized tissues: evidence at the 1-10 $\mu \mathrm{m}$ scale. Biomech Model Mechanobiol. 2003;2(1):21-36.

125. Geetha M, Singh AK, Asokamani R, Gogia AK. Ti-based biomaterials, the ultimate choice for orthopaedic implants - a review. Prog Mater Sci. 2009;54(3):397-425.

126. Price RL, Waid MC, Haberstroh KM, Webster TJ. Selective bone cell adhesion on formulations containing carbon nanofibers. Biomaterials. 2003;24(11):1877-1887.

127. Wei G, Ma PX. Structure and properties of nano-hydroxyapatite/ polymer composite scaffolds for bone tissue engineering. Biomaterials. 2004;25(19):4947-4957.

128. Karlsson $\mathrm{M}$, Pålsgård $\mathrm{E}$, Wilshaw $\mathrm{PR}$, di Silvio L. Initial in vitro interaction of osteoblasts with nano-porous alumina. Biomaterials. 2003;24(18):3039-3046.

129. Kasemo B, Gold J. Implant surfaces and interface processes. Adv Dent Res. 1999;13:8-20.

130. Hench LL. Bioceramics: from concept to clinic. J Am Ceram Soc. 1991;74(7):1487-1510.

131. Lau KH, Yoo A, Wang SP. Aluminum stimulates the proliferation and differentiation of osteoblasts in vitro by a mechanism that is different from fluoride. Mol Cell Biochem. 1991;105(2):93-105.

132. Quarles LD, Castillo SA, Drezner MK. Aluminium induced replication of osteoblast precursors: a potential mechanism underlying neo-osteogenisis. J Bone Miner Res. 1989:4 Suppl:S131.

133. Jones TR, Antonetti DL, Reid TW. Aluminum ions stimulate mitosis in murine cells in tissue culture. $J$ Cell Biochem. 1986;30(1):31-39.
134. La Flamme KE, Popat KC, Leoni L, et al. Biocompatibility of nanoporous alumina membranes for immunoisolation. Biomaterials. 2007;28(16):2638-2645.

135. Degim T. Understanding skin penetration: computer aided modeling and data interpretation. Curr Comput Aided Drug Des. 2005;1(1):11-19.

136. Saladin K. Anatomy and Physiology: The Unity of Form and Function. 4th ed. New York, NY: McGraw-Hill; 2007. ISBN: 0072875062.

137. Proksch E, Brandner JM, Jensen JM. The skin: an indispensable barrier. Exp Dermatol. 2008;17(12):1063-1072.

138. Dalby MJ, Yarwood SJ, Riehle MO, Johnstone HJ, Affrossman S, Curtis AS. Increasing fibroblast response to materials using nanotopography: morphological and genetic measurements of cell response to 13-nm-high polymer demixed islands. Exp Cell Res. 2002;276(1):1-9.

139. Dalby MJ, Ginnaras D, Riehle MO, Gadegaard N, Affrossman S, Curtis AS. Rapid fibroblast adhesion to $27 \mathrm{~nm}$ high polymer demixed nano-topography. Biomaterials. 2004;25(1):77-83.

140. Dalby MJ, Riehle MO, Sutherland DS, Agheli H, Curtis AS. Fibroblast response to a controlled nanoenvironment produced by colloidal lithography. J Biomed Mater Res A. 2004;69(2):314-322.

141. Lee $\mathrm{CH}$, Shin $\mathrm{HJ}$, Cho IH, et al. Nanofiber alignment and direction of mechanical strain affect the ECM production of human ACL fibroblast. Biomaterials. 2005;26(11):1261-1270.

142. Parkinson LG, Giles NL, Adcroft KF, Fear MW, Wood FM, Poinern GE. The potential of nanoporous anodic aluminium oxide membranes to influence skin wound repair. Tissue Eng Part A. 2009;15(12):3753-3763.

143. Chua KN, Lim WS, Zhang P, et al. Stable immobilization of rat hepatocyte spheroids on galactosylated nanofiber scaffold. Biomaterials. 2005;26(15):2537-2547.

144. Hoess A, Teuscher N, Thormann A, Aurich H, Heilmann A. Cultivation of hepatoma cell line HepG2 on nanoporous aluminum oxide membranes. Acta Biomater. 2007;3(1):43-50.

145. Buttiglieri S, Pasqui D, Migliori M, et al. Endothelization and adherence of leucocytes to nanostructured surfaces. Biomaterials. 2003;24(16):2731-2738.

146. Dalby MJ, Riehle MO, Johnstone H, Affrossman S, Curtis AS. In vitro reaction of endothelial cells to polymer demixed nanotopography. Biomaterials. 2002;23(14):2945-2954.

147. Miller DC, Thapa A, Haberstroh KM, Webster TJ. Endothelial and vascular smooth muscle cell function on poly(lactic-co-glycolic acid) with nano-structure features. Biomaterials. 2004;25(1):53-61.

148. Thapa A, Webster TJ, Haberstroh KM. Polymers with nanodimensional surface features enhance bladder smooth muscle cell adhesion. J Biomed Mater Res A. 2003;67(4):1374-1383.

149. Elisseeff J, Ferran A, Hwang S, Varghese S, Zhang Z. The role of biomaterials in stem cell differentiation: applications in the musculoskeletal system. Stem Cells Dev. 2006;15(3):295-303.

150. Li WJ, Tuli R, Okafor C, et al. A three-dimensional nanofibrous scaffold for cartilage tissue engineering using human mesenchymal stem cells. Biomaterials. 2005;26(6):599-609.

151. Manso M, Ogueta S, Herrero-Fernández P, Vázquez L, Langlet M, Garcia-Ruiz JP. Biological evaluation of aerosol-gel-derived hydroxyapatite coating with human mesenchymal stem cells. Biomaterials. 2002;23(19):3985-3990.

152. Tsioptsias C, Tsivintzelis I, Papadopoulou L, Panayiotou CA. Novel method for producing tissue engineering scaffolds from chitin, chitinhydroxyapatite, and cellulose. Mater Sci Eng C. 2009;29(1):159-164.
Nanotechnology, Science and Applications

\section{Publish your work in this journal}

Nanotechnology, Science and Applications is an international, peerreviewed, open access journal that focuses on the science of nanotechnology in a wide range of industrial and academic applications. It is characterized by the rapid reporting across all sectors, including engineering, optics, bio-medicine, cosmetics, textiles, resource sustainability

\section{Dovepress}

and science. Applied research into nano-materials, particles, nanostructures and fabrication, diagnostics and analytics, drug delivery and toxicology constitute the primary direction of the journal. The manuscript management system is completely online and includes a very quick and fair peer-review system, which is all easy to use. 